\title{
The comparative study of Chinese Design Higher Education before and after the Reform and Opening-up
}

\author{
Jiang Zheng-Qing \\ Sino-Korean School of Multi-media design \\ Shanghai University of Engineering Science, Shanghai City, China \\ Lee Dong-Hun* \\ Graduate School of Design \\ Dongseo University, Busan City, Korea
}

\begin{abstract}
Because of the social and political reasons, Chinese design higher education has come a long and difficult road. Before and after the Reform and Opening-up, Chinese design higher education system has gone through two different models:"Arts and Crafts" and "Arts \& Design". By comparing external environment and Education Concept of two models, this paper points out that the correct direction of design higher education reform is to understand and learn the advantages of two education systems.
\end{abstract}

Keywords: Chinese design higher education system, “Arts and Crafts”, “Arts \& Design”, Education Concept

\section{INTRODUCTION}

\subsection{The Background of Research}

China today, design is a fashionable term, on to the Premier, down to the general public all have attached great importance of it. Some people even claim that design is the first productivity. So what is the definition of design? In China currently authoritative view is that: design is to imagine, operations research, plan and budget, it is the creative activity of human beings to achieve a specific purpose. From the technical, economic, social, and cultural perspective, the intension of design is creative activity of the actual supplies with a specific function, external morphology, man-machine relationship and cultural meaning, which is on the purposes of functional utility and agreeableness by the certain technological skill and artistic means. It features the balance of function and estheticism, the harmonization of artistic and technical.

By 2007, Chinese design higher education had 1.4 million students in school.[1] In the face of such enormous size, we really need to clarify its development.

In the historical background when all the necessary social conditions were generally not available, especially the lack of industrialized production and commodity economy, the Chinese design higher education has followed a long and tortuous course in its establishment and development process. Thus highlighting the difficulties faced, so its development process is particularly rough and its progress is especially slow

*Corresponding author.E-mail : papamac@gdsu.ac.kr Manuscript received Jun.23, 2010 ; accepted Dec. 12, 2010 growth.

Based on studying Europe, the United States and Japan, Chinese design higher education began to develop. From SinoBritish Opium War in 1840 to the founding of People's Republic of China (PRC) in 1949, Chinese Design higher education named after "Technical Education", "Manual Education", "Pattern Education" and "Practical Arts Education" one after the other.

After 1949, large scale industrial production and society of large-scale division of labor have got great development, so as to provide the conditions for the establishment and development of design higher education. 1978 is an important time set of Chinese Social development. China's economic and political environment has undergone tremendous changes because of Reform and opening up policies. Before and after Reform and opening up, the Chinese design higher education experienced two development models of "Arts and Crafts" and "Arts \& Design”. Different external environment and education concept have created different education systems, this paper attempts to identify their inherent continuity hidden under the surface characteristics, so as to grasp the future direction of education reform by comparing two systems.

\subsection{Research Methodology}

Firstly, paper compares the external environment of Chinese design higher education before and after Reform and Openingup.

Secondly, paper compares the Education Concept of "Arts and Crafts” and “Arts \& Design”.

Thirdly, paper analyzes the inherent continuity of education 
system between “Arts and Crafts” and “Arts \& Design”.

\section{CHANGES IN THE EXTERNAL ENVIRONMENT OF CHINESE DESIGN HIGHER EDUCATION}

The external environment of Chinese design higher education includes economic and political environment. (See Table 1)

Table 1 The economic and political environment of Chinese design higher education

\begin{tabular}{|l|l|l|}
\hline & Before 1978 & After 1978 \\
\hline economic & planned economy & $\begin{array}{l}\text { Socialist Market Economy } \\
\text { with China's Characters }\end{array}$ \\
\hline political & left-leaning idea & downplay the political \\
\hline
\end{tabular}

After the founding of PRC, China ended a long war and began the peace-building. At that time the former Soviet Union's political and economic model has been a great success, its main characteristics are ownership by the whole people and a highly centralized planned economy. Planned economy is the economic system to plan the production, resource allocation and product consumption in advance by government.

With the same communist ideology, PRC's government decided to copy the planned economy model. When the first national five-year plan completed in 1957, PRC basically established $100 \%$ of the planned economy system with absolute dominance of public ownership. This lasted until 1978. In accordance with the Former Soviet model, China's socialist industrialization gave priority to the development of heavy industry and defense industry, and light industry developed slowly and kept a lot of manual production.

During this period, the Great Leap Forward, the movement to establish people's communes and "Cultural Revolution" made China's economy into complete chaos and retrogression.

From 1949 to 1978, PRC has successfully constructed a relatively independent, relatively complete industrial system. The industrialization process has entered the initial stage. But in the beginning Chinese design higher education was not linked with the industrial production, it focused its attention on arts and crafts of manual production. This was largely due to machines had not yet been universal in light industry at that time, and Chinese traditional handicrafts became the very important export goods for government. So Chinese colleges unified set up the major named after “Arts and Crafts” in 1953.

In 1978, the Third Plenary Session of the 11th Central Committee of the Chinese Communist Party (CCP) has formulated the policies of reform and opening up. After that, step by step, PRC has created Socialist Market Economy with China's Characters: the combination of public proprietorship and market economy.

Since 1978, China has got rapid economic develop, average annual growth rate of gross industrial output value was $11.5 \%$. China has already reached the middle stage of industrialization process. As a WTO member, PRC is actively moving with the tide of globalization with a positive stance of all-around opening up. There were 298 million internet users in 2008, it was the world's No.2. China has entered the information age.[2]
After the reform and opening up, with the introduction of the foreign advanced model of design education, Chinese design higher education system emphasized the role of technology and market from arts and crafts. "The Undergraduate Catalog 1998" issued by Ministry of Education ultimately determined that "Arts and Crafts" was renamed "Arts \& Design". This marks an important change in China's higher education design. Designers should not only understand technology, while trying to understand consumer psychology. At this point, the design became a profound knowledge including psychology and sociology. With the advent of information age and knowledge economy, culture became the core of Arts \& Design step by step. As a cultural activity, design affects the spiritual and ethical, moral consciousness deeply into people's lives, becomes an important part of national culture. Arts \& Design higher education at this time is no longer subordinate to or service for design practice. It changes into leading the design practice and strives to improve the design to the cultural level.

In addition to the economic environment, political environment as a very important factor also affects the Chinese design higher education. Before the Reform and Opening-up, its effect was particularly evident.

The left-leaning idea curbed development of academic thinking. In 1957, unduly broadened the Anti-Rightist Movement's scope seriously affected the normal development of Chinese design higher education. Some famous professors were persecuted because of academic point of view, for example, professor Hiun-kin Pang. He personally had over 22 years of political persecution by adhering to correct thinking of running a school of design education. [3] The ten years of “Cultural Revolution”(1966-1976) made China into melancholy stagnation and disarray. "Doubt everything", "Down with everything" and "full civil war" were main performance of "Cultural Revolution", its purpose was to prevent bourgeois revisionism. Practice has proved that "Cultural Revolution" is not and can not in any sense of revolution or social progress. During that time, Chinese design higher education was in a complete halt.

After 1978, the Third Plenary Session gave the end of the leftist error, Chinese design higher education began to grow in more relaxed political atmosphere. The Reform and Openingup introduced foreign advanced concept of design education. Chinese higher education re-entered the fast track of development.

\section{CHANGES IN EDUCATION CONCEPT OF CHINESE DESIGN HIGHER EDUCATION}

As Chinese design higher education system changes from “Arts and Crafts” to “Arts \& Design”, Education Concept has undergone tremendous changes in three: from Art Education to Design Education, from Professional Education to Competence -oriented Education, from Elite Education to Mass Education.

\subsection{From Art Education to Design Education}

"Arts and Crafts" higher education was focus on handicraft. "Arts and Crafts” was actually under the Fine Arts system, had a long history of relationships with fine arts and plastic arts. 
Chinese Fine Arts system was born out of "French academic art" and "Former Soviet realism art". So the "modeling ability" was the core at that stage.

As the domestic political environment and enclosed international environment, "Arts and Crafts" education system emphasized to absorb nourishment from the Chinese traditional art and folk art. The training objective of "Arts and Crafts" higher education triggered a debate, there were three opinions shown in Table 2. These three views represented the different requirements of social production at that time. They should be the training objectives of different levels of schools. For higher education, third view was more scientific, but the first two views were into the mainstream in the particular political environment that time. "Arts and Crafts" paid special attention to the art practice, comparatively neglected on the theory.

Table 2 three opinions of training objectives of "Arts and Crafts” [4]

\begin{tabular}{|l|l|}
\hline 1 & To train craft personnel by workshop and apprenticeship \\
\hline 2 & $\begin{array}{l}\text { To train senior Decorative Art personnel who will inherit } \\
\text { and develop the national and folk decorative art. }\end{array}$ \\
\hline 3 & $\begin{array}{l}\text { To train senior creative design talent who learns } \\
\text { European integrated design philosophy and modern } \\
\text { design methodology. }\end{array}$ \\
\hline
\end{tabular}

After the Reform and Opening-up, with the introduction of the foreign advanced model of design education, Chinese Arts \& Design higher education emphasizes the role of industrial production technology and market research. Designers should not only understand technology, while trying to understand consumer psychology. The design became a profound knowledge including psychology and sociology.

According to “The Undergraduate Catalog 1998”, training objective of “Arts \& Design” was training personnel for design, teaching, research and management. During the study, students need to learn the basic theory and basic knowledge of design. Through developing thinking ability of design, basic training of design methods and techniques, students will have the basic quality of innovative design in their professional field.

Change of enrollment system is the other evidence of development from Art Education to Design Education.

The students applied for majors of "Arts and Crafts" must pass the entrance examination including sketch painting (portrait, plaster) and colors painting (melon and fruit, container). It mainly tested students' realistic capacity. [5] In China those students are called "art major students". Their unified national college entrance examination scores can be lower than "non-art major students".

In 1986, industrial design department of Wuxi Light Industry Institute (now renamed the Southern Yangtze University) began to enroll students without the art entrance exam. This was a major reform of enrollment system of Arts \& Design higher education. Since then, the non-art students can apply for Arts \& Design, so today many of the engineering colleges recruit a large number of non-art students to study design.

\subsection{From Professional Education to Competence-oriented Education}

"Arts and Crafts" higher education system adapted to a planned economy. It was professional education which came from Former Soviet Union. Professional education trained specialists to meet the needs of the productive sectors.[6] It emphasized professional counterparts and the depth of knowledge, not breadth of knowledge.

Training objectives of "Arts and Crafts" higher education was issued by "First National Conference on Higher Education” in June, 1950. It was to train advanced nationbuilding experts who should be with high cultural level, master modern science and technology achievements, and serve the people wholeheartedly. Students should strive to be proficient in technical and professional work, turn themselves into experts and become both "red" and "expert".

By 1952, Chinese national unity college enrolling system and college graduates' distribution system has been established. Government made decision of the number of admissions of university (college) enrollment, also government made decision of graduates' employment. Government provided tuition for students.[7]Students only care about their expertise, knowledge of the other is not interested in, they can only engage in a profession. This was typical features of the planned economy model.

After the Reform and Opening-up, Arts \& Design higher education adapted to Socialist Market Economy with China's Characters. With the establishment of market economy, training objectives of Arts \& Design higher education is to cultivate talent needs of the dynamic market. So today government promotes competence-oriented education in an allround way. Graduates need to be able to engage in a variety of career. So Arts \& Design higher education emphasizes the breadth of knowledge, not depth of knowledge.

The economic environment has great impact on Arts \& Design higher education, at the same time the impact of international exchange is also a great. Era of globalization, more emphasis on international and design theoretical innovation. Arts \& Design higher education should cultivate the compound talents with good foundation and wide knowledge.

To meet the Socialist Market Economy with China's Characters, reform of Enrolling system and graduates' employment system began from the mid-1980s. Today a diversified university admission system is taking shape. The government won't provide tuition for all students (except for a small number of special majors), and the college graduates look for jobs by themselves.

\subsection{From Elite Education to Mass Education.}

During the Chinese enlarging enrollment of university since the late 1990s, the scale of China's higher education has surpassed the United States become the world's first. (see Table 3) “Arts and Crafts” higher education was Elitist Education, but Arts \& Design higher education is Mass Education.[8]

Table 3. Enrollment and Gross Enrolment Ratio (GRE) of higher education in China

\begin{tabular}{|c|c|c|}
\hline year & Enrollment (units: ten thousand) & GRE \\
\hline 1998 & 92.4 & $10.5 \%$ \\
\hline 2008 & 599 & $23.3 \%$ \\
\hline
\end{tabular}


Now Arts \& Design higher education expanded the size of school, by 2007, students in school of design education reached 1.4 million, the scale is in the top 4 in China, so more and more students have opportunities to accept the design education. Both "art major student” and "non-art student” can learn Arts \& Design.With the increase in the number of students, the quality of education is deteriorating. Mass Education does not equivalent to Vocational Education, therefore it should have a clearer position. But China's current Arts \& Design higher education is unclear, positioning confusion, its structure needs to further clarify.

\section{THE INHERENT CONTINUITY BETWEEN “ARTS AND CRAFTS” AND “ARTS \& DESIGN”}

The inherent continuity between "Arts and Crafts" and "Arts \& Design” reflects in the mode of government-led development. The major setting and course program make up the Chinese design higher education system.

\subsection{Process of establishment of "Arts and Crafts" and "Arts \& Design”}

According to "Decision on Reform of Arrangements for Schooling" issued on October 1, 1951, Chinese higher education consists of three parts: postsecondary specialized college, specialized college and university, postgraduate department.[9] This article discusses "Arts and Crafts" and “Arts \& Design" mainly refer to undergraduate education of specialized college and university.

For the development of “Arts and Crafts” higher education, from 1949 to 1978, this phase should be divided into two stages: 1949-1965 and 1966-1978. The previous phase was period of the establishment and rapid development, the latter stage remained in melancholy stagnation and disarray because of the "Cultural Revolution".

“Arts and Crafts" higher education system was set up in four steps. First step, from 1949 to 1952 the government of PRC took over and readjusted the six existing institutions with majors related art and design, such as: Beiping State Vocational Art School, Hangzhou State Vocational Art School, Sichuan Provincial Vocational Art School, Central-south China Private Vocational Art School, Shanghai Private Vocational Art School, Suzhou Private Vocational Art School.

Second step, from 1952 to1953 some reform and adjustments were carried out by the government in accordance with the Former Soviet model. Since then, only three institutions had the major related art and design. They were Central Academy of Fine Arts, LuXun Academy of Fine Arts and Southwest China State Vocational art School. In1953, government formally confirmed "Arts and Crafts" as the name of academic standards, gradually replace the original name of "Technical Education", "Design Education" and "Practical Arts Education".

The third step, Central Academy of Arts \& Design was founded in1956. This was the only specialized college of Arts and crafts at that time. It had the most professional and most full professor ranks. So Central Academy of Arts \& Design was the leader in Arts and crafts education in China.

The forth step, from 1958 to 1965 some colleges have set up additional Arts and Crafts department, such as Xi'an Fine Arts School in 1957, Zhejiang Academy of Fine Arts and Guangzhou Academy of Fine Arts in1958, Hebei Academy of Fine Arts in 1959.

Nanjing Arts Institute and Shandong University of Arts in1958, Hubei Arts Institute in 1959, Wuxi Light Industry Institute in1960, these colleges set up additional major of Arts and Crafts.

For the development of “Arts \& Design" higher education since 1978, it also can be divided into two periods: from 1978 to 1998, design higher education has realized fundamental shift from “Arts and Crafts” to “Arts \& Design”, since 1998 “Arts \& Design" is in the period of rapid development.

With the rapid industrial development and the establishment of a market economy, the community rapidly increases demand for talent of Art and design. Arts and Crafts higher education system can't keep up with the times. The reform of design higher Education rose in the 1980's. "The decision of the Communist Party of China (CPC) Central Committee on Education Reform" issued in 1985 and "The decision of CPC Central Committee and State Council on Deepening the Reform to promote quality education” issued in 1999 were the sign of transformation of Chinese higher education.

With opening-up, all kinds of design education theories, teaching models and design ideas were introduced from abroad. Government has conducted four adjustments of Arts \& Design higher education system in 1979,1987,1993,1998. Government gradually increases the importance of industrial design and integrates in majors of Arts \& Design. "The Undergraduate Catalog 1998" ultimately determined that "Arts and Crafts" was renamed “Arts \& Design”.

\subsection{Development of Major Settings}

Chinese Arts and Crafts higher education system was divided into three levels : university (college), department and major. In accordance with the needs of the social production, particular division of the productive sectors, Chinese government has exercised effective management over the major settings since 1952. Major Settings of Arts and Crafts were important part of education system. It experienced a dynamic process of change, different times in different major settings.

Table.4 showed representative major settings of Arts and Crafts.

Table 4. Developing of Major Settings of Arts and Crafts

\begin{tabular}{|l|l|}
\hline 1950 & $\begin{array}{l}\text { Department of Practical Art, Central Academy of } \\
\text { Fine Arts }\end{array}$ \\
\hline \multicolumn{2}{|c|}{ (1)eramics, (2)Dyeing \& Weaving, (3)Print Art } \\
\hline $\mathbf{1 9 5 6}$ & Central Academy of Arts \& Design \\
\hline $\begin{array}{l}\text { (1)Dyeing \& Weaving Art, (2)Ceramic Art, (3)Decorating } \\
\text { Design, (4)Interior Decoration }\end{array}$ \\
\hline $\mathbf{1 9 6 1}$ & $\begin{array}{l}\text { "Arts and Crafts school of higher education } \\
\text { programs" issued by Ministry of Culture }\end{array}$ \\
\hline $\begin{array}{l}\text { (1) Dyeing \& Weaving Art, (2) Ceramic Art, (3) Book } \\
\text { Decoration, (4) Commercial Art, (5) Murals, (6) } \\
\text { Architectural decoration }\end{array}$ \\
\hline
\end{tabular}

After Reform and Opening up, based primarily on the needs 
of the community, the Chinese government has revised "Undergraduate Catalog" four times since 1978. (see Table.5) As the transition from planned economy to market economy, Chinese government began to reflect upon Professional Education which came from Former Soviet. There is greater need for competence-oriented education in modern society. Based on competence-oriented education concept, the major settings has been optimized, compound major (such as: Arts \& Design, Industrial Design etc.) is set up instead of traditional major, to cultivate the compound talents with good foundation and wide knowledge.

Table 5. The evolution of Major Settings

\begin{tabular}{|l|l|l|}
\hline Year & & \multicolumn{1}{|c|}{ Major settings } \\
\hline 1979 & 6 & $\begin{array}{l}\text { (1)Dyeing \& Weaving Art Design, (2)Ceramic } \\
\text { Art Design, (3) Commercial Art Design, (4) } \\
\text { Book Decoration Design, (5)Decorative Murals } \\
\text { Art Design, (6)Art Designing in Industry }\end{array}$ \\
\hline 1987 & 9 & $\begin{array}{l}\text { (1) Environment Art Design, (2) industrial } \\
\text { molding design, (3)Dyeing \& Weaving Design, } \\
\text { (4) Fashion Design, (5) Ceramic Design, (6) } \\
\text { Lacquer, (7)Decorating Design, (8)Decorative } \\
\text { Art Design, (9)History and Theory of Arts and } \\
\text { Crafts }\end{array}$ \\
\hline 1993 & 8 & $\begin{array}{l}\text { (1)Dyeing \& Weaving Art Design, (2)Fashion } \\
\text { Design, (3)Ceramic Art Design, (4)Decorating } \\
\text { Art Design, (5)Environment Art Design, (6) } \\
\text { Industrial Design, (7)Decorative Art Design, } \\
\text { (8)Arts and Crafts }\end{array}$ \\
\hline 1998 & 4 & $\begin{array}{l}\text { (1)Artistic Design Theories, (2)Arts \& Design, } \\
\text { (3) Industrial Design(part), (4) Fashion Design } \\
\text { and Engineering(part) }\end{array}$ \\
\hline
\end{tabular}

Today under “Arts \& Design” there are four majors: (1) Artistic Design Theories, (2) Arts \& Design, (3) Industrial Design(part),(4)Fashion Design and Engineering(part).Chinese Arts \& Design higher education system has four levels: university (college), department, major and specialty. "The views of a number of principles on successful adjustment of major structure of undergraduate disciplines" issued in 2001 by Ministry of Education further expanded the autonomy of colleges and universities in major settings. There are a number of departments in each college, and the students in the same department may have different majors and specialties. So below the majors of "Arts \& Design" and "Industrial Design" different colleges have set up many different specialties, including Dyeing \& Weaving Art Design, Fashion Design, Ceramic Art Design, Decorating Art Design, Environment Art Design, Industrial Design, Decorative Art Design, Arts and Crafts, animation, new media design, advertising design, visual communication etc. These specialties should meet the needs of development of society.

\subsection{Development of the course program}

In 1961, based on the results of the exploration and attempt of schools, Ministry of Culture issued "Arts and Crafts school of higher education programs" to provided Five-year system and the course program for Arts and Crafts higher education. As a national course program guide, its arrangement of teaching time was clear.

The course program of "Arts and Crafts" was divided into three levels: basic courses (Fundamentals of Modeling, Basic Drawing), specialized fundamental courses (Design Fundamental) and specialized courses, vulgar called "three floors".

To enable students of Arts and Crafts to achieve to succeed in mastering many skills while specializing in one, colleges build up the "modular system" and "studio system".

"Modular system" means that the professor can complete one course as a unit in concentrated period of time. This instruction ensures the continuity of teaching. Students can focus on a particular topic of study in concentrated period of time. Work can be assured of quality.

"Studio system" means that different majors set up several special studios. Students need to enter their own major's studio and other major's studio learning and practical training. Studio system can improve students' ability of creative practice, and teaching will be integrated with production practice.

From 1978 to 1998, the course program has shown a pattern of diversification, exploring is the main features of this period.

Firstly, "Regulations Concerning Academic Degrees in the PRC” has come into force on January 1, 1981. Arts \& Design higher education set bachelor, master and doctorate degree, that is consistent with many countries. So the Five-year system of higher education has been has been adjusted into Four-year system since 1978 .

Some institutions tried exploring new curriculum and optimized structure of courses. There were "Time division system”, "The credit system” and "Interdisciplinary integrating education" etc.

“Time division system” was pilot test by Nanjing Arts Institute in 1982. Central Academy of Arts \& Design pilot test it began at 1986. Time division system made study divide into two stages: Basic Teaching (2 years) and Specialized course(2 years). Basic Teaching including Fundamentals of Modeling(sketch, color, traditional Chinese painting, sculpture), Fundamentals of Design(planar formation, three-dimensional construction, Decorative patterns, typeface, Computer Basics, drafting and perspective, Traditional Decorative Painting, Baustil Geschichte), Basis of Major and Cultural Foundation(Foreign Language, physical training, History of Chinese arts and crafts, Chinese and Foreign Art History, Art perspective).

In 1992, industrial design department of Central Academy of Arts \& Design made a new course program, all courses were divided into three categories: major basic courses(43\%), design methodology courses(18\%), design courses(39\%).

“The Credit System” was test by Guangzhou Academy of Fine Arts in 1993. The Required Courses were 60\%-70\%, Optional courses, Limited optional courses were 40\%-30\% , Free optional Course were 20\%-15\%.

In 1995, “Art Colleges' Undergraduate Teaching Program” issued by Ministry of Culture, which divided all courses into three categories: Required Courses,

After 1998, there are two directions of further development 
of course program to explore, one is to build up comprehensive interdisciplinary curriculum structure to improve innovative spirit and practical ability; the other one is to make the curriculum into "open teaching" to form multifarious links between the objectives and curriculum, to get organic integration between practical issues and traditional curriculum. For example, Shandong University of Arts has test "Interdisciplinary Integrating Education" in 2003, the course was divided into Over or manifest curriculum and Hidden or latent curriculum. [10]

Another important point of course program reform is more and more engineering courses, especially new science and technology courses have been joined into program of "Arts \& Design", such as Design Procedures and Methods, Industrial Product Standards, System Design, Survey Methods, Application of Value Analysis, Modeling Semantics, Systematology, Creatology, Design Commentary, Bionics etc.

\section{CONCLUSION}

From the previous part discussed above, Chinese design higher education develops a great process of continuity from “Arts and Crafts" to "Arts \& Design” under government-led. The original education system of "Arts and Crafts" was targeted to handicraft production requirements, the new education system of "Arts \& Design” reflecting the practical needs of industrialized society and information society adapts to large-scale industrial production and even post-industrial times. Previous talents training pattern was focus just on the elites and artists. Today it is focus on the social production and people's lives to train a large number of application-based design talents.

Arts \& Design higher education also needs to inherit and develop the Chinese national and folk decorative art, to emphasis on creative practice. These are the advantages of "Arts and Crafts" education. The future development of Chinese design higher education will be more and more affected by the market economic, the initiative should be running away from the government to the colleges. International exchanges and a variety of college forms is power to promote its development. However, the negative impact of government-led rapid expansion will be long-term.

\section{REFERENCES}

[1] Liu Yu, "Behind the expansion of design education in China: surprise or concern?”, Shenzhen Economic Daily , January 9,2008.

[2] National Bureau of Statistics of China, "The historical leap from a poverty-stricken to the modern industrial system", http://www.stats.gov.cn/tjfx/ztfx/qzxzgcl60zn/t20090921 402588674.htm

[3] Pang Hiun-kin, That came to be so, SDX Joint Publishing Campany, July. 2005.

[4] Yuan Xi-Yang, A study of The History of Development of Chinese Arts and Design Education, Beijing Institute of
Technology Press, 2003.

[5] Lin Jia-yang, Lin Jia-yang's Vision of Design-Design Innovation and Education, SDX Joint Publishing Co.Beijing, 2002, p.255.

[6] Gu Ming-yuan, "On Educational theory of the Soviet influence on China's education", Journal of Beijing Normal University (Social Science), Vol.1, 2004.

[7] Yang De-guang, "On the Eight Changes of Higher Education Institutions Reform in China”, Journal of Peking University Education Rexiew, Vol.6, no. 2, April 2008, pp105.

[8] Meng Zhongyuan, "Historical review of three Restructuring and development of Chinese Universities in 100 years", Journal of Heilongjiang Researches on Higher Education, serial no.169, 2008.

[9] Qu Shi-pei, The History of the development of university education in China, Peking University Press, Beijing, November, 2006.

[10] Xia Yan-jing, Discussion on the structure of undergraduate courses in art design, Nanjing Arts Institute,2006.

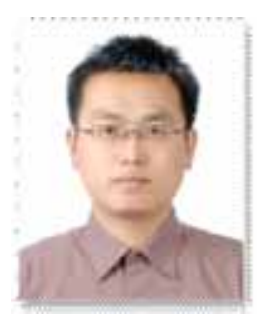

\section{Jiang Zheng-qing}

He received the B.E, M.A. in Environment Art Design from Jiangnan University, China in 2000, 2003 respectively. Since then, he has been with the Sino-Korean School of Multi-media design, Shanghai University of Engineering Science, and now he is Ph.D. in reading of multimedia design in Dongseo University, Korea. His main research interests include Multimedia design and innovation in Chinese design education.

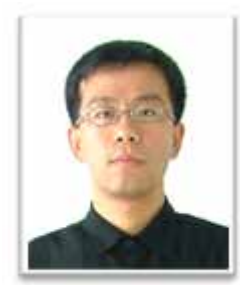

\section{LEE Dong Hun}

He is a Professor at the Division of Design, Dongseo University, Korea. He received the MST from Paris 8 University, France. His main research interests include interactive design and design education 